\title{
The inhibition of nutrient digestion by wheat pentosans
}

\author{
BY M. CHOCT AND G. ANNISON* \\ Department of Animal Science, University of Sydney, Camden, NSW 2570, Australia
}

(Received 3 September 1990 - Accepted 25 March 1991)

\begin{abstract}
Two pentosan-rich fractions (water-extractable, WEP, and alkali-extractable, AEP) were isolated from a wheat milling by-product. When both WEP and AEP were added to a commercial-type broiler diet the apparent metabolizable energy (AME), nitrogen retention, feed utilization and growth of broilers were significantly $(P<0.001)$ depressed. These depressions were closely correlated $(P<0.001)$ to the level of pentosans in the diets. At the highest level of inclusion of pentosans (equivalent to $40 \mathrm{~g}$ arabinoxylans as $A E P / \mathrm{kg}$ ) the ileal digestibilities of starch, protein and lipid were decreased by $14 \cdot 6,18 \cdot 7$ and $25.8 \%$ respectively.
\end{abstract}

Anti-nutritive effects: Non-starch polysaccharides: Broiler diets

The cell wall of cereals is comprised primarily of complex carbohydrates which are loosely termed non-starch polysaccharides (NSP). Originally NSP were considered to make minor contributions to the nutrition of chickens and other simple-stomached animals through limited fermentation in the lower bowel. In recent years, however, considerable evidence has been gathered indicating that cereal NSP exhibit anti-nutritive activity at levels as low as $<50 \mathrm{~g} / \mathrm{kg}$ in broiler diets.

To date most studies have investigated the anti-nutritive activities of the NSP from barley and rye. In barley (1-3),(1-4)- $\beta$-glucan $(30-60 \mathrm{~g} / \mathrm{kg}$ dry matter; Fincher \& Stone, 1986) causes growth depression in broilers accompanied by sticky droppings. The addition of $\beta$-glucanases to barley-based diets ameliorates the growth depression (Gohl et al. 1978; Hesselman \& Aman, 1986; Classen et al. 1988) and allows barley to be used at higher levels of inclusion in broiler diets.

Rye contains high levels of arabinoxylans (approximately $100 \mathrm{~g} / \mathrm{kg}$ dry matter; Antoniou et al. 1981). The anti-nutritive activity of these polysaccharides was demonstrated by Marquardt and co-workers (Antoniou \& Marquardt, 1981; Ward \& Marquardt, 1987) who showed that growth of broilers was depressed when pentosans isolated from rye were added to experimental diets. Supplementation of the diets with enzymes exhibiting pentosanase activity improved the nutritional value of rye-based diets (Pettersson \& Aman, 1988).

Mollah et al. (1983) and Rogel et al. (1987) reported that some Australian wheats have a low apparent metabolizable energy (AME; $<13 \mathrm{MJ} / \mathrm{kg}$ dry matter) when included in poultry diets. Wet and sticky droppings were observed when broilers were fed on these diets, as reported in birds fed on rye (Halpin et al. 1936). Pentosans are also present in wheats at appreciable levels $(50-80 \mathrm{~g} / \mathrm{kg}$ dry matter; Annison, 1990). The pentosans of wheat are similar to those of rye, consisting of a (1-4)- $\beta$-xylan chain with arabinose substituted at the O2 and O3 positions of the xylose (Fincher \& Stone, 1986). Choct \& Annison (1990) showed that when isolated wheat pentosans were added to a sorghum-

* For reprints. Present address: CSIRO Division of Human Nutrition, Glenthorne Laboratory, Majors Road, O’Halloran Hill, Adelaide, SA 5158, Australia. 
based diet containing low levels of NSP, the AME of the sorghum was depressed to an extent greater than accounted for by nutrient dilution. In addition, live-weight gain was also depressed.

In the present studies the effects of wheat pentosans on ileal digestibilities of starch, protein and lipid were examined in broiler chickens.

\section{MATERIALS AND METHODS}

\section{Isolation of wheat pentosans}

A pentosan-rich milling by-product $(\mathrm{g} / \mathrm{kg} ; 188$ arabinoxylans, 168 starch and 260 protein) was used as the source of wheat pentosans. The material was incubated in hot water $\left(1 \mathrm{~kg} / 10 \mathrm{l}, 1 \mathrm{~h}, 80-100^{\circ}\right)$ with a thermostable $\alpha$-amylase $(E C 3.2 .1 .1$; Termamyl $120 \mathrm{~L}$, Novo A/S, Denmark; $1.5 \mathrm{ml})$ to degrade the residual starch. The mixture was cooled and incubated with papain $\left(2 \mathrm{~g}, 1 \mathrm{~h}, 65^{\circ}\right)$ to remove residual protein and centrifuged $(1000 \mathrm{~g})$. The supernatant fraction was decanted and centrifuged again at high speed $(13000 \mathrm{~g}$, $30 \mathrm{~min}$ ). The clarified supernatant fraction was decanted, adjusted with ethanol (to $800 \mathrm{ml} / \mathrm{l}$ ) and the mixture was allowed to stand at room temperature for several hours. The precipitate was collected, washed with ethanol and air-dried in a forced-air oven $\left(50^{\circ}\right)$ to give a water-extractable pentosan preparation (WEP).

The insoluble material remaining after the incubation was resuspended in an equal volume of aqueous $0.2 \mathrm{M}$-sodium hydroxide at $80^{\circ}$ for $2 \mathrm{~h}$, neutralized with acetic acid and centrifuged $(1000 \mathrm{~g})$. The supernatant fraction was decanted, recentrifuged $(13000 \mathrm{~g}$, $30 \mathrm{~min}$ ) and adjusted with ethanol (to $800 \mathrm{ml} / 1$ ). The precipitate formed was dried in the same manner as the WEP to given an alkali-extractable pentosan preparation (AEP).

Several extractions were necessary to recover enough material for the animal feeding trials. The dried preparations were ground to a fine powder before inclusion in the experimental diets. Both the WEP and AEP gave viscous solutions in water indicating that they were water soluble and had retained their polymeric nature throughout the extraction procedure. In total, approximtely $420 \mathrm{~g} \mathrm{WEP}$ and $1250 \mathrm{~g} \mathrm{AEP}$ were isolated and used in the feeding trials. The greater amounts of AEP available allowed it to be used at graded levels in the present study.

\section{Bird management and $A M E$ trial}

Commercial male broilers, obtained at $1 \mathrm{~d}$ old, were maintained on a commercial starter diet for 3 weeks and then randomly allocated to six groups of equal mean live weight (eight birds per group). They were transferred to individual metabolism cages and offered the control diet $a d$ lib. for $3 \mathrm{~d}$. The experimental diets were fed for $6 \mathrm{~d}$ and feed intake and weight gain were recorded. For the last $3 \mathrm{~d}$ the excreta were collected daily, dried overnight and pooled for the determination of AME. After the last collection the birds were killed by lethal injection of phenobarbitone. The lower ileum (midway between the vitelline diverticulum and the ileo-caecal junction to $10 \mathrm{~mm}$ above the ileo-ceacal junction) was quickly removed and the contents flushed into screw-cap containers with $10 \mathrm{ml}$ distilled water. The samples were freeze-dried and stored under vacuum for future analyses.

\section{Trial diets}

Six sorghum-based commercial-type diets were formulated according to the proportions and ingredients shown in Table 1. Celite was used as an acid-insoluble marker (Vogtmann et al. 1975). The diets were cold-pelleted before feeding. 
Table 1. The ingredients of the experimental diets $(\mathrm{g} / \mathrm{kg})$

\begin{tabular}{|c|c|c|c|c|c|c|}
\hline Ingredients & 1 (Basal) & 2 & 3 & 4 & 5 & 6 \\
\hline Sorghum & 680 & 641 & 673 & 665 & 642 & 620 \\
\hline Meat and bone meal & 76 & 76 & 76 & 76 & 76 & 76 \\
\hline Soya-bean meal & 170 & 170 & 170 & 170 & 170 & 170 \\
\hline Tallow & 40 & 40 & 40 & 40 & 40 & 40 \\
\hline Sodium chloride & $2 \cdot 5$ & $2 \cdot 5$ & $2 \cdot 5$ & $2 \cdot 5$ & $2 \cdot 5$ & $2 \cdot 5$ \\
\hline L-lysine & $2 \cdot 5$ & $2 \cdot 5$ & $2 \cdot 5$ & $2 \cdot 5$ & $2 \cdot 5$ & $2 \cdot 5$ \\
\hline DL-methionine & $3 \cdot 2$ & $3 \cdot 2$ & $3 \cdot 2$ & $3 \cdot 2$ & $3 \cdot 2$ & $3 \cdot 2$ \\
\hline Premix $*$ & $5 \cdot 0$ & 50 & $5 \cdot 0$ & $5 \cdot 0$ & 5.0 & $5 \cdot 0$ \\
\hline Choline chloride $(500 \mathrm{~g} / \mathrm{kg})$ & $0 \cdot 8$ & 0.8 & 0.8 & $0 \cdot 8$ & 0.8 & $0 \cdot 8$ \\
\hline WEP & 00 & $38 \cdot 5$ & $0 \cdot 0$ & 0.0 & $0 \cdot 0$ & 0.0 \\
\hline AEP & $0 \cdot 0$ & $0 \cdot 0$ & $7 \cdot 5$ & $15 \cdot 0$ & $37 \cdot 5$ & $60 \cdot 0$ \\
\hline Celite & 20 & 20 & 20 & 20 & 20 & 20 \\
\hline
\end{tabular}

WEP, AEP, water-extractable and alkali-extractable pentosan preparations (for details, see p. 124).

* Broiler Premix (code 581891-2846A; Pfizer Agricare Pty. Ltd.) supplied (g/kg diet): vitamin E 4.0, vitamin $\mathrm{K} 1 \cdot 27$, thiamin $0 \cdot 3$, riboflavin $1 \cdot 6$, nicotinic acid $6 \cdot 0$, folic acid $0 \cdot 4$, pyridoxine hydrochloride $1 \cdot 0$, D-calcium pantothenate $3 \cdot 0$, biotin $0 \cdot 02$, ethoxyquin 25.0 , iron 4.0 , iodine $0 \cdot 2$, selenium $0 \cdot 1$, manganese $15 \cdot 0$, copper $1 \cdot 0$, cobalt 0.06 and molybdenum $0.32 ;(\mathrm{mg} / \mathrm{kg})$ : vitamin B12 $3.0 ;(\mathrm{MIU} / \mathrm{kg})$ : vitamin A 2.2 and cholecalciferol 0.7 .

\section{Analyses}

Acid-insoluble ash $(A I A)$. Diet and ileal content of samples were dried, accurately weighed and ashed $\left(480^{\circ}, 8 \mathrm{~h}\right)$, and were treated twice with boiling $4 \mathrm{M}$-hydrochloric acid. The residue was collected as the AIA. The low yields made it necessary to pool digesta from two or three birds within the same treatment for the determination of AIA, hence all the analyses relating to ileal contents were based on three replicates.

NSP. The levels of pentosans in diet ingredients and in the WEP and AEP were determined as follows. Samples were ground and then ball-milled to a fine powder. Portions $(20 \mathrm{mg})$ were added to small reaction vials (with screw caps and teflon septa) and extracted twice at $80^{\circ}$ for $5 \mathrm{~min}$ with an ethanol-water mixture $(85: 15, \mathrm{v} / \mathrm{v} ; 2 \mathrm{ml})$ to remove soluble sugars. After drying, hydrolysis of the samples was carried out using procedures described by Olsen et al. (1988). Trifluoroacetic acid $(2 \mathrm{M}, 1 \mathrm{ml})$ was added and the reaction mixtures were held at $120-125^{\circ}$ for $1 \mathrm{~h}$. After cooling and addition of an internal standard (allose, $3 \mathrm{mg} / \mathrm{ml}, 0.2 \mathrm{ml}$ ) the hydrolysate was centrifuged (bench centrifuge, $5 \mathrm{~min}$ ) and $0.8 \mathrm{ml}$ was transferred to a clean reaction tube. The excess trifluoroacetic acid was removed by codistillation with water under a stream of nitrogen gas. The dry residue was recovered in distilled water $(0.2 \mathrm{ml})$ and the free sugars were reduced by treatment with dimethylsulphoxide containing sodium borohydride $(1 \mathrm{ml}, 20 \mathrm{mg} / \mathrm{ml})$ at $40^{\circ}$ for $1.5 \mathrm{~h}$ as described by Blakeney et al. (1983). The alditols were acetylated by addition of acetic anhydride $(2 \mathrm{ml})$ and 1 -methylimidazole $(0.2 \mathrm{ml})$. The excess acetic anhydride was decomposed with distilled water $(10 \mathrm{ml})$ and the alditol acetates were extracted with dichloromethane $(1 \mathrm{ml})$. The samples were analysed using a Varian 3400 gas-liquid chromatograph instrument equipped with a Varian series 8000 auto-sampler and a flameionization detector and capillary column (DB1701, $15 \mathrm{~m}$; J. \& W. Scientific, Folsom, USA). During analysis the column was held at $200^{\circ}$ for 1 min and then raised by $5^{\circ} / \mathrm{min}$ to $220^{\circ}$ and held for $4 \mathrm{~min}$. Duplicate samples were hydrolysed and the derivatized products were determined twice.

The sugar composition of the samples was used to determine the NSP content of samples. The polymeric arabinoxylans were assumed to be comprised of a xylan backbone with 
arabinose side-chains. The levels of arabinoxylans were calculated from the levels of the component sugars as follows:

$$
\text { arabinoxylan }=(0.887 \times \text { arabinose })+(0.887 \times \text { xylose }) \text {. }
$$

Other polysaccharides (glucan, galactan and mannan) were assumed to be linear polymers and calculated using the relationship:

$$
\text { polysaccharide }=0.9 \times \text { monosaccharide. }
$$

Mixed linked $\beta$-glucans. (1-3),(1-4)- $\beta$-Glucan was determined using the method of McCleary \& Glennie-Holmes (1985) using a test kit supplied by Biocon Australia Pty Ltd.

Starch. Starch was determined using a method based on that described by Aman \& Hesselman (1984). Triplicate samples $(20 \mathrm{mg})$ were weighed into screw-capped tubes $(35 \mathrm{ml})$. Ethanol $(1 \mathrm{ml})$ and distilled water $(17 \mathrm{ml})$ were added and the tubes were held at $100^{\circ}$ for $30 \mathrm{~min}$. A thermostable $\alpha$-amylase (Termamyl $120 \mathrm{~L}$; Novo A/S, Denmark; $0.5 \mathrm{ml}$ ) was added and the tubes were heated for $1 \mathrm{~h}$ at $85^{\circ}$. After cooling, amyloglucosidase (EC 3.2.1.3; Boehringer Mannheim; $0.1 \mathrm{ml})$ and citrate buffer $(2.4 \mathrm{ml}$, $\mathrm{pH} 4.6)$ were added and the tubes were shaken for $3 \mathrm{~h}$ at $55^{\circ}$. The reaction mixtures were filtered (Whatmans No. 40 ) and the glucose concentration of the filtrate was determined using glucose oxidase (EC 1.1.3.4).

$N$. The $\mathrm{N}$ content of all samples was determined using a Kjeldahl automatic analyser (Kjel-Foss; Foss Electric, Denmark). The protein contents of WEP and AEP were calculated using the factor most appropriate for wheat proteins (i.e. $\mathrm{N} \times 5 \cdot 7$ ). For ileal samples the general factor of 6.25 was used.

Long-chain fatty acids. The long-chain fatty acid contents of the diets and of ileal samples were determined using the direct methylation method described by Outen et al. (1976), with minor modifications. Finely ground samples were dried in a desiccator over phosphorous pentoxide and accurately weighed (approximately $100 \mathrm{mg}$ ) into $20 \mathrm{ml}$ Pyrex screw-capped tubes. After addition of an internal standard $(2 \mathrm{mg}$ heptadecanoic acid in $1 \mathrm{ml}$ anhydrous methanol) the samples were dried at $35^{\circ}$ under a stream of $\mathrm{N}_{2}$ gas. Benzene $(1 \mathrm{ml})$ and methanolic $\mathrm{HCl}$ ( $3 \mathrm{ml}$; prepared by adding $1 \mathrm{ml}$ acetyl chloride dropwise to $10 \mathrm{ml}$ anhydrous methanol) were added and the samples were gently shaken for $5 \mathrm{~min}$. The tightly capped reaction mixtures were incubated at $70^{\circ}$ for $2 \mathrm{~h}$. The samples were cooled and sodium chloride $(50 \mathrm{~g} / 1 ; 7.5 \mathrm{ml})$ and $n$-hexane $(3 \mathrm{ml})$ were added and vigorously agitated. Following centrifugation $(2000 \mathrm{~g}, 5 \mathrm{~min})$ the upper layer was transferred into $8 \mathrm{ml}$ Pyrex tubes and dried at $35^{\circ}$ under $\mathrm{N}_{2}$ gas. $n$-Hexane $(2 \mathrm{ml})$ and $\mathrm{NaCl}(50 \mathrm{~g} / \mathrm{l} ; 4 \mathrm{ml})$ were added and the extraction repeated. Finally, the clarified samples were extracted with $1.5 \mathrm{ml} n$ hexane (chromatographic grade) and analysed by gas-liquid chromatography. The same instrument was used as previously described for the NSP analysis. The column was held at $180^{\circ}$ for $5 \mathrm{~min}$, raised by $2^{\circ} / \mathrm{min}$ to $190^{\circ}$ and then raised by $5^{\circ} / \mathrm{min}$ to $220^{\circ}$ and held for $2 \mathrm{~min}$.

Gross energy determination. The gross energy of diets and excreta was determined using an adiabatic bomb calorimeter (Gallenkamp).

\section{Statistical procedures}

The data were evaluated for statistical significance using analysis of variance. A standard method of regression analysis was used to assess the relationship between the level of pentosans in the diets and other variables. The sum of square of deviations was partitioned into two components, deviation caused by diet 2 (deviation, diet 2) and deviations excluding diet 2 (deviations, other), to assess the relationship further. 
Table 2. Composition $(\mathrm{g} / \mathrm{kg}$ dry matter $(D M))$ of water-extractable (WEP) and alkaliextractable $(A E P)$ pentosan preparations* from a wheat milling by-product

(Values are means of triplicate determinations)

\begin{tabular}{lcccccccc}
\hline \hline Type & Pentosan & Glucan & Mineral & $\begin{array}{c}\text { Protein } \\
\text { (nitrogen } \times \\
5 \cdot 7)\end{array}$ & Lignin & Ara/Xyl & Galactan & Mannan \\
\hline WEP† & 515 & 184.7 & 37.8 & 77.5 & 4.6 & 0.52 & 9.0 & $19 \cdot 9$ \\
AEPt & 665 & 40.3 & 47.8 & 118.0 & 64.2 & 0.66 & 8.1 & Trace \\
\hline \hline
\end{tabular}

Ara/Xyl, arabinose/xylose.

* For details, see p. 124.

$+51.6 \%$ of the total glucans is $(1-3),(1-4)-\beta$-glucans.

$\$ 94 \cdot 6 \%$ of the total glucans is $(1-3),(1-4)-\beta$-glucans.

\section{RESULTS}

Partial characterization of WEP and AEP

Chemical analysis showed that the WEP and AEP consisted of 515 and $665 \mathrm{~g}$ arabinoxylans/kg dry matter (DM). Small amounts of glucans, proteins, lignin and minerals were also present. The compositions of WEP amd AEP, as partially characterized, are shown in Table 2.

$A M E, N$ retention $(N R)$, feed conversion ratio $(F C R)$, feed intake $(F I)$, and weight gain $(W G)$

Both WEP and AEP, when added to a commercial-type broiler diet up to levels equivalent to $40 \mathrm{~g}$ arabinoxylans $/ \mathrm{kg}$, significantly $(P<0.001)$ depressed the AME of the diet, NR, FCR, WG and FI. At the level of AEP inclusion equivalent to $40 \mathrm{~g}$ arabinoxylan $/ \mathrm{kg}$ the AME of the diet dropped from $15.05 \mathrm{MJ} / \mathrm{kg} \mathrm{DM}$ to $12.48 \mathrm{MJ} / \mathrm{kg} \mathrm{DM}$, which is equivalent to a $17 \cdot 1 \%$ decrease in energy utilization. These depressions were highly correlated $(P<0.001)$ with the level of pentosans in diets. The values are presented in Table 3.

\section{Digestibilities of starch, protein and lipid in the lower ileum}

The wheat pentosans significantly depressed the digestibility of starch $(P<0.001)$ and protein $(P<0.05)$ in the ileum. There was also a noticeable effect on the digestibility of lipid (sum of long-chain fatty acids); however, statistical analysis failed to show significant difference at $P=0.05$ level due to a large between-bird variation. At the highest level of AEP inclusion (diet 6 ) the ileal digestibilities of starch, protein and lipid were depressed by $14.6,18.7$ and $25.8 \%$ respectively. High correlations $(P<0.001)$ existed between the level of pentosans in the diets and ileal digestibilities of starch, protein and lipid (Table 4).

\section{Digestibility of individual fatty acids in the lower ileum}

The digestibilities of fatty acids $\mathrm{C}_{16: 1}$ and $\mathrm{C}_{18: 2}$ were significantly $(P<0.01$ and $P<0.05$ respectively) affected by the addition of wheat pentosans. The greatest depression was recorded for fatty acid $\mathrm{C}_{18: 2}$ with the digestibility coefficient decreasing from 0.75 to 0.27 . No statistically significant effects were seen with fatty acids $\mathrm{C}_{14: 0}, \mathrm{C}_{16: 0}, \mathrm{C}_{18: 0}$ and $\mathrm{C}_{18: 1}$; however, the decreases in the digestibilities of all the fatty acids were significantly $(P<0.001)$ correlated with the level of pentosans in the diets (Table 5). 
Table 3. The effects of wheat pentosans on the apparent metabolizable energy (AME) of the diets and nitrogen retention $(N R)$, feed conversion ratio $(F C R)$, weight gain $(W G)$ and feed intake $(F I)$ of broilers

(Values are means of eight birds)

\begin{tabular}{|c|c|c|c|c|c|c|}
\hline Diet $\dagger$ & $\begin{array}{c}\text { Total } \\
\text { pentosan } \\
(\mathrm{g} / \mathrm{kg} \mathrm{DM})\end{array}$ & $\begin{array}{c}\text { AME } \\
(\mathrm{MJ} / \mathrm{kg} \mathrm{DM})\end{array}$ & $\begin{array}{c}\mathrm{NR} \\
(\mathrm{g} \mathrm{N})\end{array}$ & FCR & $\begin{array}{l}\text { WG } \\
(\mathrm{g})\end{array}$ & $\begin{array}{l}\text { FI } \\
(\mathrm{g})\end{array}$ \\
\hline 1 Control & $25 \cdot 9$ & $15 \cdot 05$ & 3.05 & 1.91 & 349 & 661 \\
\hline 2 WEP (20) & $43 \cdot 8$ & $13 \cdot 90$ & 2.79 & $2 \cdot 08$ & 312 & 637 \\
\hline $3 \mathrm{AEP}(5)$ & $30 \cdot 8$ & $15 \cdot 00$ & 289 & 1.94 & 348 & 675 \\
\hline $4 \operatorname{AEP}(10)$ & 34.9 & $14 \cdot 70$ & $2 \cdot 86$ & 1.95 & 352 & 686 \\
\hline 5 AEP (25) & $48 \cdot 0$ & $13 \cdot 34$ & $2 \cdot 42$ & $2 \cdot 49$ & 268 & 640 \\
\hline 6 AEP (40) & $65 \cdot 7$ & $12 \cdot 48$ & 1.96 & $2 \cdot 70$ & 216 & 552 \\
\hline \multicolumn{2}{|l|}{ SE (pooled) } & 0.219 & $0 \cdot 127$ & $0 \cdot 123$ & $15 \cdot 4$ & 18.9 \\
\hline \multicolumn{7}{|c|}{$F$ test and level of statistical significance } \\
\hline \multicolumn{2}{|c|}{ Diet } & $22 \cdot 28 * * *$ & $9 \cdot 98^{* * *}$ & $7 \cdot 31 * * *$ & $12-98 * * *$ & $6.46 * * *$ \\
\hline \multicolumn{2}{|c|}{ Regression on pentosan } & $109 \cdot 88 * * *$ & $46.95^{* * *}$ & $32 \cdot 41 * * *$ & $60 \cdot 25 * * *$ & $26.73^{* * *}$ \\
\hline \multicolumn{2}{|c|}{ Deviation, diet 2} & $2 \cdot 38$ & 0.25 & $0 \cdot 18$ & 0.07 & $0 \cdot 39$ \\
\hline \multicolumn{2}{|c|}{ Deviations, other } & $0-33$ & 0.89 & $1 \cdot 33$ & 1.53 & 1.73 \\
\hline
\end{tabular}

DM, dry matter; WEP, AEP, water-extractable and alkali-extractable pentosan preparations (for details, see p. 124).

*** $P<0.001$.

$\dagger$ Values in parentheses are added arabinoxylans $(\mathrm{g} / \mathrm{kg} \mathrm{DM})$. For details of composition, see p. 124 and Table 1 .

Table 4. The effects of wheat pentosans on the digestibility coefficients of starch, protein and lipid in the lower ileum of broilers

(Values are means of three replicates)

\begin{tabular}{|c|c|c|c|c|}
\hline $\operatorname{Diet} \dagger$ & Total pentosan & Starch & Protein & Lipid \\
\hline I Control & $25 \cdot 9$ & 0.96 & 0.75 & 0.93 \\
\hline 2 WEP $(20)$ & $43 \cdot 8$ & 0.91 & 0.70 & 0.87 \\
\hline 3 AEP (5) & $30 \cdot 8$ & $0 \cdot 96$ & 0.75 & 0.93 \\
\hline $4 \operatorname{AEP}(10)$ & 34.9 & 0.95 & 0.73 & 0.92 \\
\hline 5 AEP (25) & $48 \cdot 0$ & 0.92 & 0.69 & $0 \cdot 76$ \\
\hline $6 \operatorname{AEP}(40)$ & $65 \cdot 7$ & $0 \cdot 82$ & 0.61 & 0.69 \\
\hline \multicolumn{2}{|c|}{ SE (pooled) } & $0 \cdot 018$ & $0 \cdot 028$ & $0 \cdot 060$ \\
\hline \multicolumn{5}{|c|}{$F$ test and level of statistical significance } \\
\hline \multicolumn{2}{|c|}{ Diet } & $9 \cdot 406 * * *$ & $3.492^{*}$ & $2 \cdot 944$ \\
\hline \multicolumn{2}{|c|}{ Regression on pentosan } & $43 \cdot 053^{* * *}$ & $17 \cdot 193^{* * *}$ & $13 \cdot 341 * * *$ \\
\hline \multicolumn{2}{|c|}{ Deviation, diet 2} & 1.002 & $0 \cdot 218$ & 0.060 \\
\hline \multicolumn{2}{|c|}{ Deviations, other } & 2.979 & 0.016 & 0.441 \\
\hline
\end{tabular}

WEP, AEP, water-extractable and alkali-extractable pentosan preparations (for details, see p. 124).

$* P<0.05,{ }^{* * *} P<0.001$.

$\uparrow$ Values in parentheses are added arabinoxylans ( $\mathrm{g} / \mathrm{kg}$ dry matter). For details of composition, see p. 124 and Table 1 .

\section{DISCUSSION}

The pentosan-rich fractions used in the present study were similar in composition to the fractions previously isolated from a wheat milling by-product using the same methods (Choct \& Annison, 1990). The WEP contained higher levels of non-pentosan polysaccharides than the AEP. The structures of these polysaccharides were not characterized 
Table 5. The effects of wheat pentosans on the digestibility coefficients of individual fatty acids in the lower ileum of broilers

(Values are means of three replicates)

\begin{tabular}{|c|c|c|c|c|c|c|c|}
\hline \multirow[b]{2}{*}{$\operatorname{Diet}^{\dagger}$} & \multirow{2}{*}{$\begin{array}{c}\text { Total } \\
\text { pentosan }\end{array}$} & \multicolumn{6}{|c|}{ Fatty acids } \\
\hline & & $\mathrm{C}_{14}$ & $\mathrm{C}_{16: 0}$ & $\mathrm{C}_{16: 1}$ & $\mathrm{C}_{18: 0}$ & $\mathrm{C}_{18: 1}$ & $\mathrm{C}_{18: 2}$ \\
\hline 1 Control & $25 \cdot 9$ & 0.91 & 0.98 & 0.87 & 0.96 & 0.96 & $0 \cdot 75$ \\
\hline 2 WEP $(20)$ & $43 \cdot 8$ & 0.88 & 0.94 & $0 \cdot 82$ & 0.90 & 0.92 & $0 \cdot 65$ \\
\hline $3 \operatorname{AEP}(5)$ & $30 \cdot 8$ & 0.94 & 0.99 & 0.87 & 0.96 & 0.95 & 0.72 \\
\hline 4 AEP (10) & $34 \cdot 9$ & 0.92 & 0.98 & 0.86 & $0-95$ & 0.94 & 0.76 \\
\hline 5 AEP (25) & $48 \cdot 0$ & 0.88 & 0.88 & 0.72 & $0 \cdot 79$ & 0.83 & 0.39 \\
\hline \multirow{2}{*}{$\begin{array}{l}6 \text { AEP (40) } \\
\text { SE (pooled) }\end{array}$} & $65 \cdot 7$ & 0.77 & 0.83 & 0.61 & $0 \cdot 70$ & 0.79 & $0 \cdot 27$ \\
\hline & & $0 \cdot 040$ & 0.039 & 0.054 & 0.066 & 0.053 & $0 \cdot 115$ \\
\hline \multicolumn{8}{|c|}{$F$ test and level of statistical signifiance } \\
\hline \multicolumn{2}{|c|}{ Diet } & $2 \cdot 409$ & $2 \cdot 864$ & $3 \cdot 913^{* *}$ & $2 \cdot 830$ & 1.796 & $3 \cdot 547^{*}$ \\
\hline \multicolumn{2}{|c|}{ Regression on pentosan } & $10 \cdot 460 * * *$ & $13 \cdot 260^{* * *}$ & $18 \cdot 200^{* * *}$ & $13 \cdot 024^{* * *}$ & $8 \cdot 804^{* * *}$ & $15 \cdot 200 * * *$ \\
\hline \multicolumn{2}{|c|}{ Deviation, diet 2} & $0 \cdot 010$ & 0.000 & 0.090 & 0.033 & 0.034 & $0 \cdot 138$ \\
\hline \multicolumn{2}{|c|}{ Deviations, other } & 0.522 & 0.035 & $0 \cdot 417$ & $0 \cdot 366$ & $0 \cdot 350$ & 0.795 \\
\hline
\end{tabular}

WEP, AEP, water-extractable and alkali-extractable pentosan preparations (for details, see p. 124).

${ }^{*} P<0.05,{ }^{* *} P<0.01,{ }^{* * *} P<0.001$.

$\dagger$ Values in parentheses are added arabinoxylans ( $\mathrm{g} / \mathrm{kg}$ dry matter). For details of composition, see p. 124 and Table 1 .

in the present study. They were reported as glucans, galactans and mannans to indicate their polymeric nature and to distinguish them from free glucose, galactose and mannose which, if present in the milling by-product, would have been lost in the extraction procedure. The hexoses are most likely to be present as $\beta$-glucans and heteropolymers such as glucomannans and arabinogalactans which have been identified in wheat (Mares \& Stone, 1973; Fincher \& Stone, 1974). The relatively low levels of these NSP and other minor constituents of the preparations suggest that they are not likely to have had a role in the anti-nutritive activity possessed by the WEP and AEP. Arabinoxylans are the major NSP in wheat (Mares \& Stone, 1973) and both fractions were highly enriched with this pentosan material.

No attempt was made to purify further the WEP and AEP due to the difficulties in handling large amounts of this type of material. Both preparations formed very viscous solutions which limited the use of high-speed centrifugation as a means of purification. Fractional precipitation using alcohols or ammonium sulphate was also impractical due to the very large volumes of solutions required.

The arabinoxylan fractions of the WEP and AEP are probably very similar in structure. The arabinoxylans of wheat can be isolated using a series of water and alkali extractions (Saini \& Henry, 1989). The alkali cleaves ester bonds which link some of the arabinoxylans to other cell wall constituents thereby rendering them water-soluble. They are very similar in composition to the arabinoxylans which are released by water extraction alone.

Both the WEP and the AEP were found to possess anti-nutritive activity whereas previously only the alkali-soluble extract was found to be active (Choct \& Annison, 1990). A higher level of inclusion of WEP (diet 2,20 g arabinoxylan $/ \mathrm{kg}$ ) was used in the present study and statistical analysis of the data indicated that the anti-nutritive nature of the WEP was very similar to that of the AEP. Fengler \& Marquardt $(1988 a, b)$ have reported that the water-soluble pentosans of rye possess anti-nutritive activity.

The chemical analysis showed that the basal diet contained $26 \mathrm{~g}$ pentosans $/ \mathrm{kg}$ and the findings suggest that birds can tolerate up to $35 \mathrm{~g}$ total pentosan $/ \mathrm{kg}$ (diet 4 ) without 
detrimental effect. Greater experimental replication would allow the birds' tolerance to be more precisely defined but this would require large amounts of the WEP and AEP which are difficult and time-consuming to isolate on a large scale. It is clear, however, from the significant linear correlations between total dietary pentosan levels and the digestibility coefficients that the effect of pentosans is dose-dependent, which is a characteristic of many anti-nutritive compounds (Chubb, 1982).

The wheat pentosans cause a general inhibition of nutrient digestion affecting starch, fat and protein (Table 4), which indicates that they act in the same manner as the anti-nutritive NSP of rye and barley. The pentosans of rye have been reported to depress fat, protein and dry matter retention (Ward \& Marquardt, 1987; Fengler \& Marquardt, 1988b). Depressed ileal digestibilities of starch and protein have been observed in chickens fed on barley diets which had high levels of extractable viscous $\beta$-glucans (Hesselman \& Aman, 1986). Supplementation of barley-based diets with $\beta$-glucanases has been shown to improve the utilization of starch, protein and fat in broiler chickens (Edney et al. 1989).

Although a non-specific depression of digestion is suggested by the findings, it should be noted that in the case of protein the decrease in the digestibility coefficient with increasing levels of added pentosans may have been caused by increases in endogenous secretions. Low (1989) observed that elevated levels of NSP in feed can markedly increase the secretory responses of the pig gut. This would decrease the apparent protein digestibility.

A degree of specificity in the action of rye and barley NSP in depressing lipid digestion has been noted. Thus, Fengler et al. (1990) reported that a decrease in the viscosity of aqueous extracts of barley after germination (attributed to less $\beta$-glucan being present) was associated particularly with improved retention of long-chain, saturated fatty acids when the barley was fed to chickens. In broilers fed on rye-based diets similar effects have been observed (Ward \& Marquardt, 1983). In contrast, in the current study the depression in the ileal digestibility of unsaturated fatty acids $\left(C_{16: 1}, C_{18: 2}\right)$ caused by increased levels of AEP was greater than that of the saturated fatty acids, whilst no significant effects were seen in the ileal digestibility of other fatty acids determined (Table 5). The interpretation of these findings is made difficult by an inability to distinguish between the various contributions to the lipids found in ileal digesta. These include undigested dietary lipid, lipid present in endogenous secretions and microbial lipid.

The variability in all the experimental data increased as greater amounts of pentosans were added to the diets (Tables 3,4 and 5). As the feeding trials utilized individual metabolism cages this represents an increase in between-bird variation which makes it more difficult to demonstrate significant effects between treatments. The individual metabolism cages were used, however, to minimize the amount of feed and, therefore, the amount of pentosans required for the experiment. Despite the increase in the variability of the experimental data it was possible to demonstrate highly significant correlations between the total pentosans in the diet and the digestibility coefficients of starch, protein and lipid. Rogel et al. (1987) reported that when broilers were fed on low-AME wheats, greater between-bird variation was seen than when normal wheats were fed. Inhibition of starch digestion was also noted. Thus, addition of wheat pentosans appears to mimic some of the characteristics of the low-AME phenomenon.

The severe growth depression caused by the wheat pentosans was not entirely the result of decreased FI (Table 3). There was a dramatic increase in FCR and the birds showed considerable gastrointestinal stress, producing copious amounts of watery excreta. It was noted that the birds appeared dull and less responsive to the environment, which suggests that the action of the wheat pentosans was not restricted to inhibiting nutrient uptake but also, directly or indirectly, to causing malaise.

The exact mechanism of action of the NSP is unclear. A close correlation between the 
viscosity of aqueous extracts of barley and the performance of chicks has been noted (Campbell et al. 1989) and it is known that barley $\beta$-glucan can increase the viscosity of the digesta of chickens (White et al. 1981). Nutrient diffusion and absorption is inhibited by increases in viscosity in model systems (Fengler \& Marquardt, 1988 b) but whether this is the only factor involved in the anti-nutritive activity of the NSP is yet to be established.

The variability of AME values obtained from individual broilers fed on wheat diets is high compared with that of cereals with lower levels of NSP, suggesting that the antinutritive activity of wheat NSP is mediated by a highly variable factor associated with the birds (Annison \& Johnson, 1989). This factor may be the gut microflora, as in young broiler chickens large between-bird variability is found in the numbers and types of microorganism (Annison, 1989). This is supported by the studies of Wagner \& Thomas (1978) which showed that the performance of birds on rye-based diets is greatly improved with antibiotic supplementation. There is evidence that older birds utilize cereal-based diets better than younger birds. Jeroch (1987) reported that rye may be used at high levels in layer rations without production problems. Johnson (1987) compared AME values for cereals and found that when adult cockerels were used in the bioassay the values were frequently higher than those obtained using broilers. The tolerance of older birds to NSP may reflect a more active, or more stable, gut microfiora.

The findings from the current study demonstrate that wheat pentosans, in common with other cereal NSP, have an anti-nutritive activity. Further studies, however, are required to elucidate their mechanism of action.

The authors thank Professor John W. James of the University of New South Wales for his assistance in the statistical analysis of the data and for the support of the Australian Wheat Research Council and the Australian Chicken Meat Research Council.

\section{REFERENCES}

Aman, P. \& Hesselman, K. (1984). Analysis of starch and other main constituents of cereal gains. Swedish Journal of Agricultural Research 14, 135-139.

Annison, G. (1989). Determination of the AME of wheat using gnotobiotic chickens. Recent Advances in Animal Nutrition in Australia, p. 2A. Armidale, Australia: University of New England.

Annison, G. (1990). Polysaccharide composition of Australian wheats and the digestibility of their starches in broiler chicken diets. Australian Journal of Experimental Agriculture 30, 183-186.

Annison, G. \& Johnson, R. J. (1989). Relationship between AME, starch digestibility and pentosan levels in rice, sorghum and wheat diets for broiler chickens. Proceedings of the Australian Poultry Science Symposium, pp. 79-82. Sydney, Australia: Sydney University.

Antoniou, T. \& Marquardt, R. R. (1981). Influence of rye pentosans on the growth of chicks. Poultry Science $6 \mathbf{0}$, 1898-1904

Antoniou, T., Marquardt, R. R. \& Cansfield, P. E. (1981). Isolation, partial characterisation and antinutritional activity of a factor (pentosans) in rye grain. Journal of Agriculture and Food Chemistry 28, 1240-1247.

Blakeney, A. B., Harris, P. J., Henry, R. J. \& Stone, B. A. (1983). A simple and rapid preparation of alditol acetates for monosaccharide analysis. Carbohydrate Research 113, 291-299.

Campbell, G. L. Rossnagel, B. G., Classen, H. L. \& Thacker, P. A. (1989). Genotypic and environmental differences in extract viscosity of barley and their relationship to its nutritive value for broiler chickens. Animal Feed Science and Technology 26, 221-230.

Choct, M. \& Annison, G. (1990). The anti-nutritive activity of wheat pentosans in broiler diets. British Poultry Science 31, 811-821.

Chubb, L. G. (1982). Anti-nutritive factors in animal feedstuffs. In Recent Advances in Aninal Nutrition, pp. 21-37 [W. Hareseign and P. J. A. Cole, editors]. London: Butterworths.

Classen, H. L., Campbell, G. L. \& GrootWassink, J. W. D. (1988). Improved feeding value of Saskatchewangrown barley for broiler chickens with dietary enzyme supplementation. Canadian Journal of Animal Science 68 , 1253-1259.

Edney, M. J., Campbell, G. L. \& Classen, H. L. (1989). The effect of beta-glucanase supplementation on nutrient digestibility and growth in broilers given diets containing barley, oat groats or wheat. Animal Feed Science and Technology 25, 193-200. 
Fengler, A. I. \& Marquardt, R. R. (1988a). Water-soluble pentosans from rye. I. Isolation, partial purification, and characterisation. Cereal Chemistry 65, 291-297.

Fengler, A. I. \& Marquardt, R. R. (1988b). Water-soluble pentosans from rye. II. Effects on rate of dialysis and on the retention of nutrients by the chick. Cereal Chemistry 65, 298-302.

Fengler, A. I., Aherne, F. X. \& Robblee, A. R. (1990). Influence of germination of cereals on viscosity of their aqueous extracts and nutritive value. Animal Feed Science and Technology 28, 243-253.

Fincher, G. B. \& Stone, B. A. (1974). A water soluble arabinogalactan peptide from wheat endosperm. Australian Journal of Biological Sciences 27, 117-132.

Fincher, G. B. \& Stone, B. A. (1986). Cell walls and their components in cereal grain technology. In Advances in Cereal Science and Technology, vol. 8, pp. 207-295 [Y. Pomeranz, editor]. Minnesota: AACC.

Gohl, B., Alden, S., Elwinger, K. \& Thomke, S. (1978). Influence of barley $\beta$-glucanase on the feeding value of barley for poultry and moisture content of excreta. British Poultry Science 19, 41-47.

Halpin, J. G., Holmes, C. E. \& Hart, E. B. (1936). Rye as a feed for poultry. Poultry Science 15, 3-8.

Hesselman, K. \& Aman, P. (1986). The effect of $\beta$-glucanase on the utilization of starch and nitrogen by broiler chickens fed on barley of low or high viscosity. Animal Feed Science and Technology 15, 83-93.

Jeroch, H. (1987). Nutritional value of wheat, rye and triticale in broiler chickens and laying hens. World's Poultry Science Association, 6th European Symposium On Poultry Nutrition, pp. A4-A 15. London: Butterworths.

Johnson, R. J. (1987). Metabolisable energy assay systems for broiler chickens. Proceedings of the Seventh Australian Poultry and Feed Convention, pp. 127 137. Sydney, Australia: WPSA, Australian Branch.

Low, A. G. (1989). Secretory response of the pig gut to non-starch polysaccharides. Animal Feed Science and Technology 23, 55-65.

McCleary, B. V. \& Glennie-Holmes, M. (1985). Enzymic quantification of (1-3),(1-4)- $\beta$-D-glucan in barley and malt. Journal of the Institute of Brewing 91, 285-295.

Mares, D. J. \& Stone, B. A. (1973). Studies on wheat endosperm I. Chemical composition and ultrastructure of the cell walls. Australian Journal of Biological Sciences 26, 793 812.

Mollah, Y., Bryden, W. L., Wallis, I. R., Balnave, D. \& Annison, E. F. (1983). Studies on low metabolisable energy wheats for poultry using conventional and rapid assay procedures and the effects of processing. British Poultry Science 24, 81-89.

Olsen, A. C., Gray, G. M., Chiu, M.-C., Betschart, A. A. \& Turnlund, J. R. (1988). Monosaccharides produced by acid hydrolysis of selected foods, dietary fibers, and fecal residues from white and whole wheat bread consumed by humans. Journal of Agricultural and Food Chemistry 36, 300-304.

Outen, G. E., Beever, D. E. \& Fenlon, J. S. (1976). Direct methylation of long-chain fatty acids in feeds, digesta and faeces without prior extraction. Journal of the Science and Food and Agriculture 27, 419-425.

Pettersson, D. \& Aman, P. (1988). Effects of enzyme supplementation of diets based on wheat, rye or triticale on their productive value for broiler chickens. Animal Feed Science and Technology 20, $313-324$.

Rogel, A. M., Annison, E. F., Bryden, W. L. \& Balnave, D. (1987). The digestion of wheat starch in broiler chickens. Australian Journal of Agricultural Research 38, 639-649.

Saini, H. S. \& Henry, R. J. (1989). Fractionation and evaluation of triticale pentosans: Comparison with wheat and rye. Cereal Chemistry 66, 11-14.

Vogtmann, H., Pfirter, H. P. \& Prabucki, A. L. (1975). A new method of determining metabolisability of energy and digestibility of fatty acids in broiler diets. British Poultry Science 16, 531-534.

Wagner, D. D. \& Thomas, O. P. (1978). An adaptive growth response of chicks fed rye. Poultry Science 57, $230-234$.

Ward, A. T. \& Marquardt, R. R. (1983). The effect of saturation, chain length of pure triglycerides and age of bird on the utilization of rye diets. Poultry Science 62, 1054-1062.

Ward, A. T. \& Marquardt, R. R. (1987). Antinutritional activity of a water-soluble pentosan-rich fraction from rye grain. Poultry Science 66, 1665-1674.

White, W. B., Bird, H. R., Sunde, M. L., Burger, W. C. \& Marlett, J. A. (1981). The viscosity interaction of barley beta-glucan with Trichoderma viride cellulase in the chick intestine. Poultry Science 60, 1043 1048. 